Халіман, Оксана. «Імператив емоційної актуалізації дії: вираження оцінних значень». Лінгвостилістичні студіï, вип. 11, 2019, с. 166-73.

Khaliman, Oksana. "Imperative of Emotional Actualization of Action as a Means of Conveying Evaluative Meaning”. Linguostylistic Studies, iss. 11, 2019, pp. 166-73.

Удк 881.161.2'36

https://doi.org/10.29038/2413-0923-2019-11-166-173

\title{
ІМПЕРАТИВ ЕМОЦІЙНОЇ АКТУАЛІЗАЦІЇ ДІЇ: ВИРАЖЕННЯ ОЦІННИХ ЗНАЧЕНЬ
}

\author{
Оксана Халіман \\ Харківський національний педагогічний університет ім. Г. С. Сковороди, \\ Харків, Україна
}

У статті описано окремі типи транспонованого вживання імперативних форм для вираження аксіологічних смислів (модель «Грошей їй дай», модель «Отак і роби добро») в українській мові. Транспонована граматична одиниця стає засобом моделювання іронії: іронічне самоспонукання до дії моделює висловлювання автокомунікативного типу - мовець спрямовує на себе «імпульс» вербалізованої дії, оцінюючи її негативно через, на його думку, недоречність.

Ключові слова: аксіологічні смисли, імперативні форми, іронічне самоспонукання, транспоноване вживання, українська мова.

\section{IMPERATIVE OF EMOTIONAL ACTUALIZATION OF ACTION AS A MEANS OF CONVEYING EVALUATIVE MEANING Oksana Khaliman}

H. S. Skovoroda Kharkiv National Pedagogical University, Kharkiv, Ukraine

In some linguistic contexts, verb forms, except a primary function of a category, can perform secondary functions, which reveal their specific features in the context of the grammar of evaluation. Despite the importance of the issue, few attempts have been made to study it in modern linguistics.

The goal of the article is to characterize particular types of the transposed use of imperative forms in modeling axiological content. The study seeks to identify the modeling mechanisms of evaluation, based on the use of imperative forms in action emotional actualization (model Грошей їй дай; model Отак і роби добро) and highlight aspectually the features of the figurative use of the imperative forms as devices of tropeistics.

The model Грошей їй дай manifests the ironic interpretation of one's duties or somebody's requirement to perform it which is expressed by the using imperative form, conveying negative speaker's attitude to the person who motivates or encourages its performance, and to the action itself. There is no indication of the action doer in the constructions with the value of unwillingness and the pejorative attitude concerns the verbalized action. The grammatical igrem simulates the transposing use of the form: the speaker "tries on" himself an imperative form with an indicative tinge of obligation / compulsion, which causes a negative assessment.

(C) Халіман О., Східноєвропейський національний університет імені Лесі Українки, 2019.

Це стаття відкритого доступу на умовах CC BY-NC 4.0 
The imperative form in the model Отак і роби добро contains an indicative shade of meaning associated with an already accomplished or hypothetical action that appears inappropriate in view of other events. The speaker ironically «tries on» on himself an «impulse» to perform the action and evaluates it negatively. Grammatical igrem is modeling the transposed form of imperative used in the indicative meaning. Unlike the model Грошей їй $\partial a \breve{u}$, there is no semantic meaning of duty or compulsion. The intention to perform the action comes from the speaker. The action is evaluated negatively as inappropriate because of certain circumstances.

Key words: axiological meanings, imperative models, ironing self-doing, Ukrainian language.

Вступ. Факти об'єктивної дійсності мовець може сприймати як дійсні (реальні) або як можливі (ірреальні) чи бажані. Характер віднесеності висловленого мовцем до дійсності, або модальність, передається в мові лексичними, морфологічними, синтаксичними та інтонаційними засобами.

Категорія способу дієслів - граматична категорія, що, як відомо, виражає відношення дії до дійсності та реалізується в сучасному українському мовленні формами трьох граматичних значень: дійсний, наказовий та умовний способи. І. Вихованець умотивовує безпідставність виділення грамеми дійсного способу, оскільки це «породило парадоксальне співвідношення категорій, суть якого полягала в тому, що категорія часу посідає якесь «подвійне» граматичне положення, маючи ознаки автономної й неавтономної одиниці. 3 одного боку, вона членується на грамеми теперішнього, минулого й майбутнього часу, а 3 другого - сама входить у ролі підпорядкованої одиниці (грамеми) в категорію способу...» (Вихованець 95-96). У сучасному мовознавстві домінує думка, що категорія способу чотирикомпонентна: грамема умовного способу, що передає значення гіпотетичної дії чи гіпотетичного процесу й стану, та грамеми наказового, спонукального й бажального способу, що виражають значення бажаної дії чи бажаного процесу й стану з різним рівнем апелятивності (Вихованець, і Городенська 257).

Дієслівні форми способу, «крім своєї первинної категорійної функції, у відповідних мовленнєвих контекстах можуть набувати вторинних функцій» (Вихованець, і Городенська 263) - способових і часових, що демонструє певну специфіку й у ракурсі граматики оцінки.

Мета дослідження - схарактеризувати окремі типи транспонованого вживання імперативних форм для моделювання аксіологічних смислів. Зазначена мета передбачає розв'язання таких завдань: 1) описати механізми моделювання оцінки, що грунтуються на вживанні імператива емоційної актуалізації дії (модель «Грошей їй дай», модель «Отак і роби добро»); 2) аспектуально висвітлити особливості переносного вживання імперативних форм як засобів тропеїстики.

Матеріал і методи дослідження. Матеріалом дослідження слугують художні твори й розмовне мовлення сучасної української мови. У процесі аналізу було застосовано метод спостереження в процесі систематичного, 
цілеспрямованого сприйняття об'єкта, описовий метод (прийоми внутрішньої й зовнішньої інтерпретації). Для дослідження оцінної семантики використано методи компонентного, контекстуального, порівняльного аналізів; методи вибірки - для відбору фактичного матеріалу.

Результати дослідження та дискусії. Основне значення імператива зазвичай трактують так: «...імператив $\epsilon$ формою прямого звертання, у якому мовець спонукає адресата до дії, вираженої дієсловом» (Исаченко 7). Особливості вживання транспонованих форм наказового способу здавна привертали увагу мовознавців. Найбільш активними в транспозиційних переходах К. Городенська називає форми наказового способу (Вихованець, i Городенська 263). Серед способових форм І. Піддубська також саме імперативні вважає найпродуктивнішими щодо можливості транспозиції та вираження вторинних смислів, зокрема оцінних: «...він [імператив] транспонується у сфери значень індикатива й кон'юнктива і має досить розгалужену систему метафоричних уживань. Основна конотація, що супроводжує переносне вживання форми наказового способу, пов'язана 3 появою суб'єктивно-оцінних смислів» (10), оскільки суб'єктивність є важливим складником модального плану імператива.

Досліджуючи полісемію імператива в російській мові, Е. Фортейн пояснює, як різноманітні переносні значення («повинність», «умова», «неочікуваність») пов'язані з основним семантичним поняттям імператива 'наявність імпульсу до імперативної дії. Учений описує ознаку «імпульс», наявність якої в основному директивному значенні очевидна, а в непрямих уживаннях вона також продовжує відігравати певну роль. Ця ознака складається 3 компонентів: 1) «наявність імпульсу до здійснення чи репрезентації дії» й 2) «заклик адресата виявити певну причетність щодо цієї дії» та проявляється в усіх типах уживання імператива. Ця ознака $є$ ядром: навколо неї утворюється весь комплекс значень імператива. «Імпульс», як правило, набуває інших смислів: мовець хоче звернути особливу увагу на неочікуваний чи небажаний характер ситуації (Фортейн), що, як показує ілюстративний матеріал, пов'язано й 3 актуалізацією аксіологічних смислових відтінків.

У попередніх своїх публікаціях авторка цієї розвідки описала імператив емоційної актуалізації дії - переносні вживання форм наказового способу, що супроводжуються породженням оцінних значень (модель «Інші гуляють, а я працюй!») (Халіман, «Транспозиція»). Було констатовано, що під час такого вживання граматичну ігрему моделює транспоноване вживання дієслівних форм: імперативна форма 2-ої особи однини, уживаючись в індикативній функції, виражає значення вимушеної необхідності здійснення дії й супроводжується негативною оцінкою, засудженням, висловленням неправомірності дії, невдоволенням нею. Імперативний відтінок форми забезпечує сприйняття дії як нав'язаної ззовні, через що вона й отримує відповідну оцінку. Унаслідок 
транспонованого вживання дієслівної форми спостерігаємо розширення граматичних можливостей первинно імперативної форми: вираження граматичних значень часу, роду / особи, числа, що відбувається завдяки відповідній синтагматиці (Халіман, Граматика 330-338).

Семантичну й прагматичну схожість із такою моделлю простежуємо під час переносного функціювання імператива зі значенням повинності / вимушеності на зразок: $A$ потім ще йди, значить, і воюй за пана, іди, значить, воші в окопах годуй, іди - голову під кулі підставляй, кишки на колючий дріт вимотуй. А кому од цього користь? - питаю сам себе (Яновський 159).

Специфіка такої моделі полягає у відсутності підмета-діяча, однак указівка на нього може бути подана в інші частині речення, порівн.: $y$ Катрі дитинка занедужала, а тут обід панам звари, вечерю звари та город скопай, обсій, та ще пані гримає: «Нічого не робиш, ледащо! Дурно хліб мій їси! (Вовчок 130); Повертався додому й думав: «I навіщо я $\mathrm{mi}$ прокляті три тисячі поклав на рахунок? Позавчора ж поклав, а тепер забирай!» (Дімаров 255).

Однак, як демонструє ілюстративний матеріал, переважна більшість таких переносних уживань імперативних форм стосується власне мовця, що іронічно «наказує» самому собі, чим виражає негативне ставлення до номінованої дії. Крім того, імперативна форма частіше омовлює ірреальну (гіпотетичну) дію, порівн.:

Він ніяково відповів, що прийшов до неї більше за тим, щоб по душі погомоніти. І вона страшенно обурилась:

- Душі йому треба! За рубля душу йому вивертай! Для тебе моя душа під спідницею (Підмогильний 523).

Значення повинності в таких висловлюваннях необхідно відмежовувати від значення вимушеності. У висловлюваннях з відтінком повинності завжди присутній розпорядник - істота (істоти), що вимагає певних дій від виконавця. Обов'язково актуалізується сема «волевиявлення», пов'язана 3 розпорядником, що моделює негативне ставлення до нього й до дії, названої імперативом, напр.: Ото як п'ють [куркулі] удома, то самовар опівночі став їм, то десь за самогоном біжи.. Як повпиваються та як розбалакаються, страшно робиться (Головко 137). У конструкціях зі значенням вимушеності така сема відсутня, змушує здійснювати дію не істота, а ситуація, обставини (Дмитриева 7).

У досліджуваній моделі, як бачимо, можна спостерігати номінацію розпорядника займенниковими формами 3-ої особи (його / йому, їі / їй, їх / їм). Таке вживання фіксуємо навіть у разі його присутності в розмові, що теж слугує засобом моделювання негативної оцінки, оскільки в сучасному українському мовленнєвому етикеті чинною $\epsilon$ заборона щодо вживання займенників він (вона) й похідних у присутності іншого, того, власне, кого й стосується цей займенник (Халіман, Граматика 57-58), напр.:

- І грошей мені дай. 
- Грошей їй дай... Більше нічого? (з розм. мовл.).

Отже, тут має місце аплікація засобів для вираження негативних смислів. Індикативний відтінок форми (Грошей їй дай = Я повинен давати їй гроші) пов'язаний зі значенням повинності й викликає незадоволення мовця відповідною гіпотетичною дією.

Принципово важливим, на думку Л. Дмитрієвої, $є$ розмежування осіб виконавця й носія суб'єктивної оцінки, оскільки з останнім пов'язане негативне ставлення, протест, що $€$ обов'язковим компонентом такої моделі. Згадана вище дослідниця зробила висновок, що семантика аналізованих конструкцій накладає обмеження на лексичне наповнення імперативних форм. Крім того, ці форми характеризуються фіксованим уживанням дієслівних форм НДВ. Дію репрезентують як 'надлишково тривалу, вона вкрай обтяжлива для виконавця'. Тому тут неможливі імперативні форми ДВ, а також форми, що мають семантику переривчастих дій (Дмитриева 7).

Справді, у більшості прикладів спостерігаємо використання форм НДВ, однак, як демонструє останній, наведений вище приклад, функціювання імперативної форми ДВ у досліджуваній моделі також можливе. Причиною цього, як видається, $\epsilon$ специфіка діалогічності розмовного мовлення, адже один 3 учасників діалогу автоматично відтворює форму, ужиту в попередній репліці.

М. Шелякін звертає увагу на імперативні форми другої особи, що в поєднанні з часткою (рос.) хоть (аналогічно в українській мові - хоч) означають вимушений вихід із ситуації, що склалася, як правило, небажано, напр.: Він відчув тривогу, сум'яття. Все так неждано навалилося на нього. Хоч сам біжи через пущу. Але ж наказ мусив бути виконаний. За всяку ціну (Бедзик 250) (хоч сам біжи = сам має бігти). Вимушена дія, пов'язана з неочікуваними, раптовими змінами, зазвичай набуває негативної оцінки.

Справді, більшість таких конструкцій виражають негатив, проте зустрічаємо й інше значення: висока позитивна оцінка чогось прогнозує дію, виражену імперативними формами із часткою хоч, напр.: I виходить Наталка із хати, I виносить вам кухоль води, І така в неї мова багата, Хоч в словник їі, чисту, введи (Забашта 20).

Як приклад М. Шелякін також наводить фразеологізми, порівн. (рос.): хоть волком вой, хоть святых выноси, хоть ложись и умирай, хоть караул кричи (Шелякин 123). В українській мові також мають місце подібні фразеологізми: хоч у вухо бгай, хоч з гармати (гармат) стріляй (гати), хоч відбавляй, хоч вовків (собак) гони (ганяй), хоч греблю (гать) гати, хоч до рани прикладай (притули). Позитивне чи негативне значення окремих фразеологізмів, характер оцінки залежно від контексту можуть змінюватися. Напр., фразеологізм хоч до рани прикладай / притули ('про людину добру, з лагідною вдачею або про людину, що удає з себе добру, лагідну'), порівн.: Став Панкратій Семенович таким запобігливо- 
солоденьким, таким м'якеньким, що хоч до рани прикладай (Козаченко 173); Такий любий отой Василь, хоч до рани приклади його (Ірчан 264); - Що новенького чувати у вас, Настуню? - голос баби Омелянихи сьогодні був такий прихильний - хоч до рани прикладай (Качура 169).

На основі такого вживання імператива сформувалося функціювання паремії хоч сядь $і$ плач, що іï використовують під час оповіді про пейоративно марковані події, порівн.: ...таке було його життя, що хоч сядь та й плач, а тепер, через цю кляту холеру, ще гірше буде (Іваничук 51).

Отже, іронічна інтерпретація повинності, чиєїсь вимоги, репрезентована імперативною формою, виражає негативне ставлення мовця, гіпотетичного виконавця названої дії до особи, що мотивує ії виконання, і власне до самої дії. У конструкціях зі значенням вимушеності вказівка на виконавця відсутня, пейоративне ставлення спрямоване на омовлену дію.

Граматичну ігрему моделює транспоноване вживання форми: насправді наказує не мовець: він моделює висловлювання автокомунікативного типу - начебто «приміряє» на себе імперативну форму з індикативним відтінком повинності / вимушеності, що й викликає негативну оцінку. Конструкціям властива своєрідна інтонація, що свідчить про незадоволення суб'єктом відповідною ситуацією.

До подібних висловлювань долучаються «негативні за змістом речення 3 формою другої особи однини в узагальнено-особовому значенні» (Шелякин 124), напр.: Отак i вір тобі! (з розм. мовл.). Індикативний відтінок форми (я вірив тобі / я збирався вірити тобі) пов'язаний зі значенням передбачуваної чи здійсненої дії й викликає в мовця незадоволення нею, напр.: ...що отак бідувала, не вміла жити інакше. Забула і про піч, про борщ і кашу, сиділа на лаві та думала - чи й справді могла отак жити на світі людина? Але тітка Тонька недовго сиділа... «Отак i вір людям. Вір отак, навіть найближчим...» (Збанацький 132); "Отак вір людям, як цей майор Сільченко! - гнівався Пужай. - Хотів же як краще! Чого лиш не доводиться пережити й стерпіти!» - понуро хитав головою. У кожного своя доля... От Пужая вона кидає на цій війні, як хвиля тріску (Автомонов 27).

У разі вживання форм на позначення 1-ої чи 3-ої особи спостерігаємо аплікацію засобів вираження оцінки: ГЗ способу та ГЗ особи (напр., імперативну форму 2-ої ос. одн. застосовують для самономінації, порівн: Отак роби людям добро = Я робив людям добро).

Імперативна форма містить індикативний відтінок, пов'язаний зі здійсненою чи гіпотетичною дією, що виявляється недоречною з огляду на інші події. Мовець іронічно «приміряє» на себе «імпульс» до реалізації дії й оцінює його негативно. Так само несхвалення викликає особа, пов'язана 3 
недоречними обставинами. Граматичну ігрему моделює транспоноване вживання імперативної форми в індикативному значенні.

Висновки та перспективи досліджень. Отже, з транспонованим уживанням імперативних форм пов'язане моделювання оцінних (пейоративних) відтінків значення.

Описані механізми мають спільні й відмінні риси. На відміну від моделі «Грошей їй дай», де вербалізується вимушена дія, через що негативно оцінюється і розпорядник (у разі наявності), і сама дія, у конструкції на зразок «Отак і роби добро» сема повинності / вимушеності відсутня. Інтенція до виконання дії виходить від самого мовця (діяча). Дія оцінюється негативно як недоречна через інші обставини. Тотожним, як було зазначено, $\epsilon$ наявність «імпульсу», завдяки якому мовець «приміряє» на себе дію й отримує можливість їі оцінити.

Транспоноване вживання граматичної одиниці стає засобом моделювання тропів: іронічний наказ самому собі оцінюється негативно, оскільки, як відомо, експліцитне значення іронічного висловлювання $\epsilon$ протилежним власне його імпліцитному змістові за оцінною інтерпретацією.

У перспективі плануємо аналіз інших моделей транспонованого вживання імперативних форм в аспекті граматики оцінки.

\section{Список використаних джерел}

Автомонов, Павло. П'ята застава. Київ, 1989.

Бедзик, Юрій. Меч Торквемади. Київ, 2003.

Вовчок, Марко. Оповідання та повісті. Київ, 1961.

Головко, Андрій. Твори. В 2 т. Т. 1. Київ, 1986.

Дімаров, Анатолій. Містечкові історії. Київ, 1987.

Забашта, Любов. Пісня і хліб. Київ, 1961.

Збанацький, Юрій. Кують зозулі. Київ, 1983.

Іваничук, Роман. Вода з каменю. Львів, 1982.

Ірчан, Мирослав. Вибрані твори. В 2 т. Т. 2. Київ, 1958.

Качура, Яків. Вибрані твори. Київ: Радянський письменник, 1953.

Козаченко, Василь. Блискавка. Київ, 1962.

Підмогильний, Валер'ян. Оповідання. Повість. Романи. Київ, 1991.

Яновський, Юрій. Твори. В 5 т. Т. 5. Київ, 1959.

Avtomonov, Pavlo. Piata zastava. Kyiv, 1989.

Bedzyk, Yurii. Mech Torkvemady. Kyiv, 2003.

Vovchok, Marko. Opovidannia ta povisti. Kyiv, 1961.

Holovko, Andrii. Tvory. 2 vols. Vol. 1. Kyiv, 1986.

Dimarov, Anatolii. Mistechkovi istorii. Kyiv, 1987.

Zabashta, Liubov. Pisnia i khlib. Kyiv, 1961.

Zbanatskyi, Yurii. Kuiut zozuli. Kyiv, 1983.

Ivanychuk, Roman. Voda z kameniu. Lviv, 1982.

Irchan, Myroslav. Vybrani tvory. 2 vols. Vol. 2. Kyiv, 1958.

Kachura, Yakiv. Vybrani tvory. Kyiv: Radianskyi pysmennyk, 1953.

Kozachenko, Vasyl. Blyskavka. Kyiv, 1962. 
Pidmohylnyi, Valerian. Opovidannia. Povist. Romany. Kyiv, 1991.

Yanovskyi, Yurii. Tvory. 2 vols. Vol. 5. Kyiv, 1959.

\section{Список використаної літератури}

Вихованець, Іван. Частини мови в семантико-граматичному аспекті. Київ, 1989.

Вихованець, Іван, і Городенська, Катерина. Теоретична морфологія української мови. Академічна граматика української мови. Київ, 2004.

Дмитриева, Людмила. Внеимперативное употребление формы повелительного наклонения повелительного наклонения. Автореф. дис. ...канд. филол. наук: 10.02.01. Москва, 1993.

Исаченко, Александр. «К вопросу об императиве в русском языке». Русский язык в школе, № 6, 1957, с. 7-14.

Піддубська, Інна. Модальна і темпоральна транспозиція дієслівних форм. Автореф. дис. ...канд. філол. наук: 10.02.01. Донецьк, 2001.

Фортейн, Эгберт. «Полисемия императива в русском языке». Вопросы языкознания, № 1 , 2008, c. 3-24.

Халіман, Оксана. «Транспозиція імперативних форм як механізм породження оцінних значень (на матеріалі української та російської мов)». Науковий вісник Східноєвропейського національного університету ім. Лесі Українки. Серія "Філологічні науки», № 6 (307), 2015, с. 137-142.

Шелякин, Михаил. Функциональная грамматика русского языка. Москва, 2001.

\section{References}

Vykhovanets, Ivan. Chastyny movy v semantyko-hramatychnomu aspekti. Kyiv, 1989.

Vykhovanets, Ivan, and Horodenska, Kateryna. Teoretychna morfolohiia ukrainskoi movy. Akademichna hramatyka ukrainskoi movy. Kyiv, 2004.

Dmitrieva, Ljudmila. Non-imperative use of the imperative form of the imperative. PhD Thesis Abstract. Moskva, 1993.

Isachenko, Aleksandr. "K voprosu ob imperative v russkom jazyke". Russkij jazyk v shkole, no. 6, 1957, pp. 7-14.

Piddubska, Inna. Modal and temporal transposition of verb forms. PhD Thesis Abstract. Donetsk, 2001.

Fortuin Egbert. "Polisemija imperativa v russkom jazyke". Voprosy Jazykoznanija (Topics in the Study of Language), no. 1, 2008, pp. 3-24.

Khaliman, Oksana. "The transposition of imperative forms as a mechanism of generating value values (on the material of Ukrainian and Russian)". Naukovyi visnyk Skhidnoievropeiskoho natsionalnoho universytetu im. Lesi Ukrainky. Seriia "Filolohichni nauky", no. 6 (307), 2015, pp. 137-142.

Sheljakin, Mihail. Funkcional'naja grammatika russkogo jazyka. Moskva, 2001.

Стаття надійшла до редколегії 01.10.2019 